\title{
Romantic drama of Sandhyakala ning Majapahit by Sanusi Pane and its implications for literary learning in senior high school
}

\author{
Ni Wayan Ayu Permata Sari*) \\ Universitas Indraprasta PGRI \\ *) Correspondences author: Jalan Raya Tengah No. 80, RT.9/RW.8, Gedong, Pasar Rebo, RT.1/RW.3, Gedong, Kota Jakarta \\ Timur, Daerah Khusus Ibukota Jakarta 13760, Indonesia; \\ e-mail: niwynayups@gmail.com
}

\begin{abstract}
This study aims to reveal the romanticism contained in Sandhyakala ning plays Majapahit works Sanoesi Pane. The method used adallah descriptive qualitative content analysis techniques. The results of this study stated that plays Sandhyakala ning Majapahit works Sanoesi Pane contains romanticism. The third characteristic of romanticism analyzed, namely awareness of wild nature, the uniqueness and distinctiveness of the individual and the longing for the presence of a social order that is warm, everything depicted in the play. In the play, parts 1 and 2 illustrate the awareness of the wild. Then, sections 2 and 3 illustrate the uniqueness and distinctiveness of the individual. Sections 3, 4, and 5 describe a longing for the presence of a social order that is warm. The attitude shown through dialaog and characters in the text of the characteristics of romanticism. So, script Sandhyakala ning Majapahit is told through the flow of romanticism. The implications of this research for the study of literature in high school is as an alternative material of literary learning materials.
\end{abstract}

Keywords: Romanticism, script, Sandhyakala ning Majapahit.

\begin{abstract}
Article History: Received: 17/03/2017; Revised: 23/04/2017; Accepted: 30/04/2017; Published: 05/05/2017
How to Cite (MLA 7th): Sari, Ni Wayan Ayu Permata. “Romantic drama of Sandhyakala ning Majapahit by Sanusi Pane and its implications for literary learning in senior high school." Hortatori: Jurnal Pendidikan Bahasa dan Sastra Indonesia 1.1 (2017): 41-51. Print/Online. Copyrights Holder: Sari, Ni Wayan Ayu Permata. First Publication: Hortatori Jurnal Pendidikan Bahasa dan Sastra Indonesia (2017).
\end{abstract}

\section{Pendahuluan}

Harjana (1981), sastra merupakan bagian kehidupan dari suatu kebudayaan yang tumbuh dan berkembang di tengah-tengah masyarakat. Dengan karya sastra, pengarang dapat melukiskan dan mencerminkan zaman dan masyarakat. Pengarang dapat berbicara tentang cinta kasih, kesedihan, kebahagiaan, penderitaan, penindasan, tipu muslihat, kejujuran, keheroismean dan perjuangan. Pada hakikatnya, sastra adalah pengungkapan kehidupan lewat bentuk bahasa, bahasa merupakan jembatan penghubung antara pengarang dengan pembaca (Djojosuroto, 2007).

Mencintai sastra artinya awal pengenalan suatu kebudayaan yang sedang berkembang di masyarakat. Jenis sastra yang umum diketahui oleh masyarakat adalah puisi, cerpen, dan drama. Berdasarkan jenis yang ada, drama yang akan diangkat pada penelitian ini. Drama diteliti karena tidak hanya menganalisis teksnya saja, tetapi juga dari segi pementasannya. Hal tersebut menambah nilai dari drama itu sendiri.

N. Riantiarno dalam bukunya Menyentuh Teater menyatakan, drama berasal dari bahasa Yunani, dramai. Artinya 'bertindak/berlaku/berbuat/beraksi'. Drama juga sering diartikan sebagai kehidupan 
manusia yang berbuat atau beraksi. Berangkat dari 'sebab' dan 'berakibat' (Riantiarno, 2003). Senada dengan N. Riantiarno, Kinayati Djosuroto dalam bukunya Dasar-dasar Teori Apresiasi Prosa menyatakan bahwa drama adalah kisah lakuan (kisah yang dilakonkan). Istilah drama berasal dari dramai yang artinya berbuat menirukan suatu kejadian (2007).

Maman S. Mahayana dalam tulisannya, Lingkungan Hidup dalam Sastra, para sastrawan di belahan dunia manapun, justru sudah sejak dahulu mengingatkan pentingnya persahabatan dengan alam, kembali ke alam (back to nature). Persahabatan dengan alam dan kepedulian terhadap lingkungan, telah menempatkan alam dan lingkungan hidup sebagai sumber ilham dan kreasi imajinatif sastrawan. Maman menambahkan, karya-karya sastra beraliran romantisisme (abad ke-16 Masehi) sudah sarat dengan napas kerinduan pada alam. Revolusi industri yang mengentak dunia kala itu telah mencerabutkan manusia dari sisi kemanusiaan, religiositas, dan spiritualitasnya. Pada konteks demikian, sastra menjadi medium "Pembersih" ketercerabutan manusia dari akar kemanusiaannya itu. Hal serupa juga telah mewarnai panggung sastra Indonesia. Dari karya klasik hingga kontemporer, suara tentang alam dan kejernihan membaca kondisi lingkungan telah lama digaungkan.

Membahas tentang zaman romantik, peneliti akan membahas pula Sanoesi Pane. Sanoesi Pane menganut aliran romantik. Penelitian sastra beraliran romantisme selalu berprinsip bahwa karya sastra merupakan cermin kehidupan realistik (Endraswara, 2008). Aliran tersebut sangat tepat untuk menganalisis naskah drama Sandhyakala ning Majapahit karya Sanoesi Pane.

\section{Metode}

Penelitian ini hendak menemukan romantisisme naskah drama Sandhayakala ning Majapahit karya Sanoesi Pane. Pemilihan naskah drama ini bukan tanpa alasan. Peneliti ingin menemukan romantisisme tanpa melupakan sejarah Bangsa Indonesia. Selain itu, penelitian ini sangat menarik karena tidak hanya sastra saja yang diungkapkan tetapi sejarahpun juga diungkap.

Naskah drama Sandhayakala ning Majapahi terdapat pertentangan antara kalangan bawah dan kalangan atas (raja), deskripsi alam, imajinatif, dan perasaan yang kuat. Hal-hal tersebut sebenarnya garapan wilayah romantisisme. Tampaknya, hal-hal tersebut mengindikasikan adanya hubungan dengan romantisisme. Seberapa jauh hubungan tersebut, maka diadakanlah penelitian ini.

Adapun penelitian ini untuk mengingatkan kita pada sejarah bangsa Indonesia yaitu masa kejayaan Majapahit serta kemunduran Majapahit. Dengan mengangkat naskah drama Sandhyakala ning Majapahit karya Sanoesi Pane sebagai objek penelitian, hasilnya diharapkan dapat menjadi bahan pembelajaran sastra di SMA. Dalam kemampuan mengaplikasikan naskah drama berarti mampu mengenal pengarang dengan baik serta memahami sejarah akan bangsa Indonesia.

\section{Hasil dan Diskusi}

Hasil analisis data mengenai romantisisme dalam naskah drama Sandhyakala ning Majapahit ditemukan ciri-ciri romantisisme, yaitu:

\section{Kesadaran akan adanya alam liar berdasarkan karakter}

Pada bagian ini terdapat ciri romantisisme, seperti pada kutipan berikut:

Kama Wijaya : "Damar Wulan, rahasia alam sudah terbuka kepada mata jantung hatimu. Akan tetapi ketahuilah kiranya, bahwa pengetahuanmu akan membawa jiwa sukmamu ke dalam jurang gelap gulita. Tahu masin bukan bahagia. Bahagia masuk ke dalam hati, kalau jiwa satu dengan Brahma, kalau cinta kepada dunia. Janganlah engkau seperti karang, tetapi seperi pohon beringin, melindungi orang yang lelah payah. Bukalah hatimu bagi dunia, hiduplah engkau selama-lamanya juga kalau di dunia jasmani." (hlm 28)

Keterangan: Rahasia alam, karang, dan pohon beringin adalah tentang rakyat jelata. Rakyat jelata yang memerlukan bantuan. Alam yang memberi inspirasi. Sosok alam disini tidak mudah ditaklukan, justru sebaliknya alam dilihat menjadi alam yang menjulang dalam sosok yang memesona dan sekaligus dahsyat serta mengerikan. 
Damar Wulan: "Paduka Batara Kamawijaya tahulah hamba maksud tuan. Sadarlah hamba akan kekurangan, dalam dasar jiwa sukmaku. Tersenyum kulihat alam sekarang, bunyi gamelan riuh rendah. Akan tetapi, bagaimanakah perasaanku sekarang ini bisa kekal dalam hatiku? (hlm 28) Keterangan: Tersenyum kulihat alam sekarang, bunyi gamelan riuh rendah adalah alam dianggap sebagai suatu organisme, atau dengan kata lain, suatu kesatuan yang selalu mengembangkan potensi-potensi bawaannya.

Damar Wulan : "Daulat Perabu, purbakala agama kita muda segar, meninggikan derajat jiwa Dewata cuma tanda saja, berhala hanya perkakas indah untuk menghalaukan perasaan kita. Demikian juga air suci, pesta agama. Dewata sebenarnya jiwa kita. Kehidupan bertakhta dalam hati. Kebenaran ini dapat di kitab, diakui sekalian orang budiman. (hlm 60)

Keterangan: Berhala, air suci, dan pesta agama adalah simbol dalam beragama. Alam dianggap sebagai suatu organisme, atau dengan kata lain, suatu kesatuan yang selalu mengembangkan potensi-potensi bawaannya.

Damar Wulan: "Perkataan ini tidak bisa kuketahui akan artinya. Brahma terjadi oleh kekuatan dirinya sendiri dan ia menjadi tiga. Yang tiga inilah azas dunia.(hlm 8)

Keterangan: Brahma terjadi oleh kekuatan dirinya sendiri dan ia menjadi tiga. Yang tiga inilah azas dunia terlihat bahwa alam menjadi satu-kesatuan yang selalu mengembangkan potensi-potensi bawaannya. Itu berarti romantisisme memandang alam sebagai suatu keseluruhan (totalitas).

Wisynu: "Dunia ini tidak pernah terjadi, karena tidak pernah tidak ada. Dunia ini senantiasa di sini dan tidak akan pernah menjadi musnah. Lihat matahari, Damar Wulan ! manusia membilang, bahwa ia bulat dan panas. Tetapi ini angan-angan belaka. Nama matahari itu pendapatan manusia dan begitu juga sifat bulat dan panas. Matahari bukan matahari dan bukan bulat dan panas. Akan tetapi bukan demikian pula. Mengertikah engkau, Damar Wulan?" (hlm. 13)

Keterangan: Dunia ini tidak pernah terjadi, karena tidak pernah tidak ada. Dunia ini senantiasa di sini dan tidak akan pernah menjadi musnah merupakan alam. Alam yang dimaksud bukanlah alam yang mudah ditaklukan, seperti dalam paradigma modernitas, melainkan alam yang menjulang dalam sosok yang memesona dan sekaligus dahsyat serta mengerikan. Alam yang masih murni menjadi guru sekaligus inspirasi. Seperti matahari, bulat, dan panas merupakan inspirasi yang bisa dipetik manusia melalui alam.

Wisynu: “... Siapa yang hendak mengenal kehidupan, harus melupakan nama-nama dan sifatsifat itu..." (hlm. 14)

Keterangan: Siapa yang hendak mengenal kehidupan, harus melupakan nama-nama dan sifat-sifat itu merupakan alam yang dipandang bukanlah alam yang mudah ditaklukan, melainkan alam yang menjulang dalam sosok yang memesona dan sekaligus dahsyat serta mengerikan. Alam yang masih murni menjadi guru sekaligus inspirasi.

Wisynu: “... Hentikanlah berpikir, hancurkanlah dunia maya dan satukanlah dirimu dengan jiwa segala benda..." (hlm. 15)

Keterangan: Hentikanlah berpikir, hancurkanlah dunia maya dan satukanlah dirimu dengan jiwa segala benda merupakan alam yang dipandang bukanlah alam yang mudah ditaklukan. Itu berarti romantisisme memandang alam sebagai suatu keseluruhan (totalitas).

Kamawijaya: “... Bukalah hatimu bagi dunia, hiduplah engkau selama-lamanya, juga kalau di dunia jasmani." (hlm. 28)

Keterangan: Bukalah hatimu bagi dunia merupakan totalitas yang diungkapkan oleh romantisisme. Alam dipandang suatu yang tidak untuk ditaklukan dan menjadi suatu keseluruhan. 
44 Romantic drama of Sandhyakala ning Majapahit by Sanusi Pane and its implications for literary learning in senior high school

\section{Keunikan dan kekhasan individu seperti perasaan (passion) dan imajinasi berdasarkan karakter}

Ciri romantisisme berikutnya adalah keunikan dan kekhasan individu seperti perasaan (passion) dan imajinasi, seperti pada kutipan berikut:

Damar Wulan: "Siapakah yang menjadikan Brahma?"

Maharesi : "Ia terjadi oleh kekuatan dirinya sendiri" (hlm. 8)

Keterangan: Kekuatan dirinya sendiri adalah sebuah keunikan dan kekhasan individu yang dianggap sebagai kekayaan dan kelebihan. Individu dan diri menjadi pusat semesta.

Damar Wulan : “... Orang menyembah dewa-dewa akan tetapi tidak seorang yang pernah melihat mereka. Aku ingin mengetahui dan melihat dengan tenang. Tidak senang hati saya membaca dan mendengar permainan pikiran saja. (hlm. 9)

Keterangan: Orang menyembah dewa tetapi tidak pernah melihat. Hal tersebut menurut romantisisme dipandang bahwa manusia bukan semata-mata sebagai makhluk yang rasional, melainkan lebih sebagai makhluk irasional dan sering kali dikendalikan oleh ketaksadarannya.

Maharesi: "Damar Wulan, ingatlah, bahwa kewajiban kita yang terutama ialah menyembah dewa dan yang kedua memperhatikan isi-isi buku suci dengan pimpinan guru..." (hlm 9)

Keterangan: Menyembah dewa dan yang kedua memperhatikan isi-isi buku suci merupakan bagian dari keirasionalan manusia. Manusia sering kali dikendalikan oleh ketaksadarannya. Hal tersebut keunikan dan kekhasan individu yang dianggap oleh romantisisme.

Wisynu: "Akulah Wisynu, yang engkau cari. Aku bertakhta dalam hatimu, baru sekarang engkau lihat. Bertanyalah engkau kepadaku, kepada kehidupan sendiri." (hlm 13)

Keterangan: Aku bertakhta dalam hatimu, Bertanyalah engkau kepadaku, kepada kehidupan sendiri termasuk ciri romantisisme karena Wisynu adalah Dewata. Dewata yang selama ini dicari oleh Damar Wulan. Hal itulah yang dijelaskan kaum romantik yaitu membiarkan Tuhan dalam dirinya dan mengalirkan kreasinya.

Wisynu : “... Nirwana dalam hatimu sendiri. Insyaflah kamu, bahwa engkau ialah daku, Batara Wisynu." (hlm 15)

Keterangan: Nirwana dalam hatimu sendiri. Insyaflah kamu, bahwa engkau ialah daku, Batara Wisynu, dalam romantisisme membiarkan Tuhan dalam dirinya dan mengalirkan kreasinya. Romatisisme sangat mengistimewakan kedaulatan individu.

Damar Wulan : "Daulat Perabu, purbakala agama kita muda segar, meninggikan derajat jiwa Dewata cuma tanda saja, berhala hanya perkakas indah untuk menghalaukan perasaan kita. Demikian juga air suci, pesta agama. Dewata sebenarnya jiwa kita. Kehidupan bertakhta dalam hati. Kebenaran ini dapat di kitab, diakui sekalian orang budiman. (hlm 60)

Keterangan: Dewata sebenarnya jiwa kita adalah menggambarkan suatu alam yang bersatu dengan jiwa. romantisisme membiarkan Tuhan dalam dirinya dan mengalirkan kreasinya. Romatisisme sangat mengistimewakan kedaulatan individu.

\section{Kerinduan akan hadirnya suatu tatanan sosial yang hangat berdasarkan karakter}

Ciri romantisisme selanjutnya adalah kerinduan akan hadirnya suatu tatanan sosial yang hangat, seperti pada kutipan berikut:

Anjasmara: "Tuan berpangkat kesatria, bukan sudera dan pekerjaan ini tidak layak tuan kerjakan." (hlm 17)

Keterangan: Kesatria dan sudera adalah tingkatan kasta. Dalam tatanan sosial, hal tersebut seperti mengelompokkan manusia. Oleh karena itu, romantisisme rindu akan tatanan sosial yang hangat.

Damar Wulan: "Raden Ajeng Anjasmara, jikalau terjadi penghinaan kasta, negeri pun runtuh, tidak tertolong. Keadaan Majapahit jadi begini karena rakyat dihina-hinakan, diperas, dan 
dipijak. Sebulan baru saya di sini, tetapi sudah banyak kulihat. Kesatria menikam orang bawahan untuk mencoba tajam kerisnya. Sudera dipandang sebagai hewan, negeri buat kaum bangsawan. Kesateria sekalian kaya-kaya, rakyat meratap karena lapar. Dasar negeri sudah lapuk, sebentar lagi Majapahit hancur.” (hlm. 17-18).

Keterangan: Penghinaan kasta, kesateria, dan sudera merupakan contoh yang terjadi dalam tubuh Majapahit. Hal tersebut sudah jelas digambarkan oleh dialog Damar Wulan. Dialog di atas mengungkapkan betapa angkuhnya kesateria kepada sudera dan hal tersebut menurut romantisisme merupakan garapannya yaitu rindu akan suatu tatanan sosial yang hangat.

Anjasmara: "Yang kucintai Damar Wulan, bukan pekerjaannya sekarang ini. Aku tahu, bahwa tuan sudah jadi seperti ini, karena perintah yang tidak patut." (hlm. 18)

Keterangan: Perintah yang tidak patut adalah gambaran tentang buruknya tatanan sosial yang ada dalam Majapahit. Hal tersebut sesuai dengan romantisisme yaitu rindu akan suatu tatanan sosial yang hangat.

Layang Setera: “... Ingat Anjasmara, engkau sudah dipinang oleh Adipati Singasari. Dan janganlah lupa akan pangkatmu...” (hlm. 21)

Keterangan: Pangkat dianggap yang penting dalam suatu sosial di Majapahit. Perbedaan tersebut membuat dampak sosial yang kurang baik. Oleh karena itu, ciri romantisisme yaitu rindu akan suatu tatanan sosial yang hangat cocok dalam permasalahan yang terjadi di Majapahit.

Dewi Suhita: "perkataan paman benar sekali, tetapi apakah patut diperbuat lagi? Cobalah sebut jalan yang baik. Waktu dulu kehormatan sungguh jadi kepala balatentara, sekarang sukar mencari orang yang suka jadi senapati." (hlm. 35)

Keterangan: Waktu dulu kehormatan sungguh jadi kepala balatentara, sekarang sukar mencari orang yang suka jadi senapati ialah bentuk romantisisme yang merindukan suatu tatanan sosial yang hangat. Dahulu kehormatan Majapahit sangat dijunjung, sekarang kepentingan pribadi jauh lebih penting.

Utusan: "Perabu, patik diutus tuan hamba Menak Koncar mempersembahkan kepada Perabu, bahwa Bupati Perabalingga telah menyerahkan ibu negeri kepada Adipati Menak Jingga."Dewi Suhita: "Bertambahlah sudah orang durhaka. Di Jawadwipa tidak ada kesatria lagi. Pabila berangkat Menak Jingga untuk menyerang Majapahit?" (hlm 35)

Keterangan: Menak Koncar mempersembahkan kepada Perabu, bahwa Bupati Perabalingga telah menyerahkan ibu negeri kepada Adipati Menak Jingga dan bertambahlah sudah orang durhaka,di Jawadwipa tidak ada kesatria lagi menggambarkan bahwa terjadi pengkhianatan yang akan menyebabkan kemunduran dalam Majapahit. Bagian tersebut yang merupakan garapan romantisisme yakni rindu suatu tatanan sosial yang hangat.

Damar Wulan: "memang rakyat mau berontak. Akan tetapi Perabu, adalah sebabnya. Rakyat sengsara bukan kepalang, karena kelakuan beberapa menteri karena yuran terlalu tinggi, karena harta tidak terlindung. Di kaki singgasana Seri Perabu orang banyak kelaparan dan meratap minta perlindungan. Perabu, patik enggan menumpahkan darah tidak bersalah.” (hlm 44)

Keterangan: Rakyat sengsara dan yuran terlalu tinggi, karena harta tidak terlindung melukiskan bahwa rakyat jelata sudah pasti sensara dan tertindas akibat ketidakberdayaanya. Oleh karena itu, Damar Wulan menginginkan rakyat jelata diperlakukan adil sehingga tatanan sosial yang hangat bisa terwujud.

Patih : "Rakyat harus dikekang keras. Ia bukan dalam sengsara, hanya dibujuk orang khianat. Jikalau duli Seri Perabu memberi hati sekali saja, rakyat tentu bertambah berani dan meminta bertambah banyak.

Damar Wulan baru sebentar di Majapahit, tidak tahu keadaan negeri.

Beri perintah, Perabu, kepada senapati memaksa rakyat pulang ke rumah.

Hanya tangan kuat dapat memerintah dengan selamat..." (hlm 44) 
Keterangan: Rakyat harus dikekang keras dan Hanya tangan kuat dapat memerintah dengan selamat melukiskan bahwa rakyat adalah sesuatu yang rendah dan dapat ditaklukan serta dikuasai oleh yang kuat. Tangan kuat adalah sesuatu yang kuat, dimana bisa mengatur apa saja dengan kearoganannya.

Damar Wulan: “... Dan kaum kesatria, ya Perabu, murka kepada patik, karena tidak bisa mereka lagi memeras rakyat jelata. Kesatria dulu artinya penyamun, tidak mengindahkan jiwa dan harta. Mereka tidak dapat hukuman, karena hakim negeri menginjak hak rakyat bawahan. Patik membela rakyat jelata, menjunjung tinggi akan kebenaran, menguatkan singgasana Seri Perabu..." (hlm 61)

Keterangan: Kesatria, memeras rakyat jelata, dan hakim negeri menginjak hak rakyat bawahan merupakan kesateria dan rakyat jelata berbeda. Rakyat jelata adalah rendah, sedangkan kesateria adalah tinggi. Hakim negeri pun turut menginjak rakyat bawahan. Suatu tatanan sosial yang hangat bisa terwujud apabila hal tersebut bisa dihapuskan.

\section{Kesadaran akan adanya alam liar berdasarkan alur/plot}

Pada bagian ini terdapat ciri romantisisme, seperti pada kutipan berikut:

Kama Wijaya : "Damar Wulan, rahasia alam sudah terbuka kepada mata jantung hatimu. Akan tetapi ketahuilah kiranya, bahwa pengetahuanmu akan membawa jiwa sukmamu ke dalam jurang gelap gulita.

Tahu masin bukan bahagia. Bahagia masuk ke dalam hati, kalau jiwa satu dengan Brahma, kalau cinta kepada dunia.

Janganlah engkau seperti karang, tetapi seperi pohon beringin, melindungi orang yang lelah payah.

Bukalah hatimu bagi dunia, hiduplah engkau selama-lamanya juga kalau di dunia jasmani." (hlm 28)

Keterangan: Rahasia alam, karang, dan pohon beringin adalah tentang rakyat jelata. Rakyat jelata yang memerlukan bantuan. Kamawijaya sedang berdialog dengan Damar Wulan mengenai kesusahan yang diderita rakyat jelata (kaum bawah) karena ulah kesateria. Kesateria kini tinggal nama, sifatnya sudah berubah menjadi perampok. Hal tersebut pun dijadikan salah satu dialog yang diujarkan oleh Damar Wulan. Dialog ini berada dalam bagian dua naskah drama. Alam yang memberi inspirasi. Sosok alam disini tidak mudah ditaklukan, justru sebaliknya alam dilihat menjadi alam yang menjulang dalam sosok yang memesona dan sekaligus dahsyat serta mengerikan.

Damar Wulan: "Paduka Batara Kamawijaya tahulah hamba maksud tuan. Sadarlah hamba akan kekurangan, dalam dasar jiwa sukmaku. Tersenyum kulihat alam sekarang, bunyi gamelan riuh rendah. Akan tetapi, bagaimanakah perasaanku sekarang ini bisa kekal dalam hatiku? (hlm 28) Keterangan: Tersenyum kulihat alam sekarang, bunyi gamelan riuh rendah adalah alam dianggap sebagai suatu organisme, atau dengan kata lain, suatu kesatuan yang selalu mengembangkan potensi-potensi bawaannya. Dialog ini terlibat oleh Kamawijaya dan Damar Wulan. Dialog ini berada pada bagian dua dari naskah drama. Dialog ini masih bercerita tentang permasalahan antara kesateria dan rakyat jelata.

Damar Wulan : "Daulat Perabu, purbakala agama kita muda segar, meninggikan derajat jiwa Dewata cuma tanda saja, berhala hanya perkakas indah untuk menghalaukan perasaan kita. Demikian juga air suci, pesta agama.

Dewata sebenarnya jiwa kita. Kehidupan bertakhta dalam hati. Kebenaran ini dapat di kitab, diakui sekalian orang budiman. (hlm 60)

Keterangan: Berhala, air suci, dan pesta agama adalah simbol dalam beragama. Alam dianggap sebagai suatu organisme, atau dengan kata lain, suatu kesatuan yang selalu mengembangkan potensi-potensi bawaannya. Dialog ini berada pada bagian lima dari naskah drama. Pada bagian ini terjadi di bangsal witana. Dialog ini terjadi ketika Damar Wulan berdialog dengan Dewi Suhita. Dimana Damar Wulan difitnah karena Damar Wulan mengujarkan bahwa sekarang agama hanya takhyul. 
Damar Wulan : "Perkataan ini tidak bisa kuketahui akan artinya. Brahma terjadi oleh kekuatan dirinya sendiri dan ia menjadi tiga. Yang tiga inilah azas dunia.(hlm 8)

Keterangan: Brahma terjadi oleh kekuatan dirinya sendiri dan ia menjadi tiga. Yang tiga inilah azas dunia terlihat bahwa alam menjadi satu-kesatuan yang selalu mengembangkan potensi-potensi bawaannya. Itu berarti romantisisme memandang alam sebagai suatu keseluruhan (totalitas). Dialog ini berada pada bagian satu dari naskah drama. Dialog ini terjadi antara Damar Wulan dengan Maharesi. Damar Wulan pada bagian ini menanyakan mengapa Brahma menjadikan dunia ini? Siapakah ang menjadi Brahma? Bagaimana timbulnya dunia ini?. Banyak pertanyaan Damar Wulan yang seharusnya tidak dipikirkan oleh manusia karena pertanyaan tersebut sudah terdapat dalam buku-buku suci.

Wisynu: "Dunia ini tidak pernah terjadi, karena tidak pernah tidak ada. Dunia ini senantiasa di sini dan tidak akan pernah menjadi musnah. Lihat matahari, Damar Wulan! manusia membilang, bahwa ia bulat dan panas. Tetapi ini angan-angan belaka. Nama matahari itu pendapatan manusia dan begitu juga sifat bulat dan panas. Matahari bukan matahari dan bukan bulat dan panas. Akan tetapi bukan demikian pula. Mengertikah engkau, Damar Wulan?" (hlm. 13)

Keterangan: Dunia ini tidak pernah terjadi, karena tidak pernah tidak ada. Dunia ini senantiasa di sini dan tidak akan pernah menjadi musnah merupakan alam. Alam yang dimaksud bukanlah alam yang mudah ditaklukan, seperti dalam paradigma modernitas, melainkan alam yang menjulang dalam sosok yang memesona dan sekaligus dahsyat serta mengerikan. Alam yang masih murni menjadi guru sekaligus inspirasi. Seperti matahari, bulat, dan panas merupakan inspirasi yang bisa dipetik manusia melalui alam. Dialog ini berada pada bagian satu dari naskah drama. Dialog ini terjadi pada Wisynu dan Damar Wulan. Wisynu disini seperti Tuhan karena naskah drama ini menunjukkan munculnya Wisynu selalu ketika Damar Wulan sedang termenung. Pada bagian ini pun masih tentang pertanyaan-pertanyaan Damar Wulan tentang dunia dan Tuhan.

Wisynu: “... Siapa yang hendak mengenal kehidupan, harus melupakan nama-nama dan sifatsifat itu...” (hlm. 14)

Keterangan: Siapa yang hendak mengenal kehidupan, harus melupakan nama-nama dan sifatsifat itu merupakan alam yang dipandang bukanlah alam yang mudah ditaklukan, melainkan alam yang menjulang dalam sosok yang memesona dan sekaligus dahsyat serta mengerikan. Alam yang masih murni menjadi guru sekaligus inspirasi. Dialog ini berada pada bagian satu dari naskah drama. Dialog ini terjadi pada Wisynu dan Damar Wulan. Pada bagian ini pun masih tentang pertanyaan-pertanyaan Damar Wulan tentang dunia dan Tuhan.

Wisynu: “... Hentikanlah berpikir, hancurkanlah dunia maya dan satukanlah dirimu dengan jiwa segala benda..." (hlm. 15)

Keterangan: Hentikanlah berpikir, hancurkanlah dunia maya dan satukanlah dirimu dengan jiwa segala benda merupakan alam yang dipandang bukanlah alam yang mudah ditaklukan. Itu berarti romantisisme memandang alam sebagai suatu keseluruhan (totalitas). Dialog ini berada pada bagian satu dari naskah drama. Dialog ini antara Wisynu dan Damar Wulan. Pada bagian ini pun masih tentang pertanyaan-pertanyaan Damar Wulan tentang dunia dan Tuhan. Wisynu berusaha menjelaskan mengenai pertanyaan-pertanyaan Damar Wulan.

\section{Keunikan dan kekhasan individu seperti perasaan (passion) dan imajinasi berdasarkan alur/plot}

Ciri romantisisme berikutnya adalah keunikan dan kekhasan individu seperti perasaan (passion)dan imajinasi, seperti pada kutipan berikut:

Damar Wulan: "Siapakah yang menjadikan Brahma?"

Maharesi : "Ia terjadi oleh kekuatan dirinya sendiri" (hlm. 8)

Keterangan: Kekuatan dirinya sendiri adalah sebuah keunikan dan kekhasan individu yang dianggap sebagai kekayaan dan kelebihan. Individu dan diri menjadi pusat semesta. Dialog ini berada pada bagian satu dari naskah drama. Dialog ini antara Damar Wulan dan Maharesi (Nenek Damar Wulan). Dialog ini terjadi di Asyrama Paluh Amba. Damar Wulan pada bagian ini menanyakan mengapa Brahma menjadikan dunia ini? Siapakah yang menjadi Brahma? Bagaimana 
timbulnya dunia ini?. Banyak pertanyaan Damar Wulan yang seharusnya tidak dipikirkan oleh manusia karena pertanyaan tersebut sudah terdapat dalam buku-buku suci.

Damar Wulan: “... Orang menyembah dewa-dewa akan tetapi tidak seorang yang pernah melihat mereka. Aku ingin mengetahui dan melihat dengan tenang. Tidak senang hati saya membaca dan mendengar permainan pikiran saja. (hlm. 9)

Keterangan: Orang menyembah dewa tetapi tidak pernah melihat. Hal tersebut menurut romantisisme dipandang bahwa manusia bukan semata-mata sebagai makhluk yang rasional, melainkan lebih sebagai makhluk irasional dan sering kali dikendalikan oleh ketaksadarannya. Dialog ini berada pada bagian satu dari naskah drama. Dialog ini antara Damar Wulan dan Maharesi (Nenek Damar Wulan). Damar Wulan berpendapat bahwa orang menyembah dewadewa yang tidak pernah mereka lihat merupakan takhyul. Menurut Damar Wulan, Tuhan itu yang bisa ia lihat dan ketahui dengan terang. Bukan melalui berhala, air suci, atau apapun yang tidak terlihat. Bagian pertama lebih menceritakan pada pertanyaan Damar Wulan mengenai mengapa Brahma menjadikan dunia ini? Siapakah yang menjadi Brahma? Bagaimana timbulnya dunia ini?

Maharesi: "Damar Wulan, ingatlah, bahwa kewajiban kita yang terutama ialah menyembah dewa dan yang kedua memperhatikan isi-isi buku suci dengan pimpinan guru..." (hlm 9)

Keterangan: Menyembah dewa dan yang kedua memperhatikan isi-isi buku suci merupakan bagian dari keirasionalan manusia. Manusia sering kali dikendalikan oleh ketaksadarannya. Hal tersebut keunikan dan kekhasan individu yang dianggap oleh romantisisme. Dialog ini terdapat pada bagian satu dari naskah drama. Dialog ini antara Damar Wulan dan Maharesi. Mengapa Brahma menjadikan dunia ini? Siapakah yang menjadi Brahma? Bagaimana timbulnya dunia ini?. Banyak pertanyaan Damar Wulan yang seharusnya tidak dipikirkan oleh manusia karena pertanyaan tersebut sudah terdapat dalam buku-buku suci. Bagi Damar Wulan, yang terpenting adalah Tuhan yang nyata.

Wisynu: "Akulah Wisynu, yang engkau cari. Aku bertakhta dalam hatimu, baru sekarang engkau lihat. Bertanyalah engkau kepadaku, kepada kehidupan sendiri." (hlm 13)

Keterangan: Aku bertakhta dalam hatimu, Bertanyalah engkau kepadaku, kepada kehidupan sendiri termasuk ciri romantisisme karena Wisynu adalah Dewata. Dewata yang selama ini dicari oleh Damar Wulan. Hal itulah yang dijelaskan kaum romantik yaitu membiarkan Tuhan dalam dirinya dan mengalirkan kreasinya. Dialog ini terdapat pada bagian satu dari naskah drama. Dialog ini antara Damar Wulan dan Wisynu. Dialog Wisynu menjelaskan pada Damar Wulan bahwa ia tidak perlu bertanya dan mencari jawaban kepada siapapun, karena diri sendirinyalah yang bisa menjawab atas pertanyaannya selama ini.

Wisynu: “... Nirwana dalam hatimu sendiri. Insyaflah kamu, bahwa engkau ialah daku, Batara Wisynu." (hlm. 15)

Keterangan: Nirwana dalam hatimu sendiri. Insyaflah kamu, bahwa engkau ialah daku, Batara Wisynu, dalam romantisisme membiarkan Tuhan dalam dirinya dan mengalirkan kreasinya. Romantisisme sangat mengistimewakan kedaulatan individu. Dialog ini terdapat pada bagian satu dari naskah drama. Dialog ini antara Damar Wulan dan Wisynu. Dialog Wisynu lebih menjelaskan bahwa pertanyaan Damar Wulan yang sudah melewati batas sehingga Wisynu pun menegaskan bahwa Wisynu itu adalah Damar Wulan. Dalam tubuh Damar Wulan terdapat Wisynu. Jawaban yang ia cari selama ini adalah ternyata berada dalam dirinya sendiri.

Damar Wulan: "Daulat Perabu, purbakala agama kita muda segar, meninggikan derajat jiwa Dewata cuma tanda saja, berhala hanya perkakas indah untuk menghalaukan perasaan kita. Demikian juga air suci, pesta agama. Dewata sebenarnya jiwa kita. Kehidupan bertakhta dalam hati. Kebenaran ini dapat di kitab, diakui sekalian orang budiman. (hlm 60) 
Keterangan: Dewata sebenarnya jiwa kita adalah menggambarkan suatu alam yang bersatu dengan jiwa. romantisisme membiarkan Tuhan dalam dirinya dan mengalirkan kreasinya. Romatisisme sangat mengistimewakan kedaulatan individu. Dialog ini terdapat pada bagian lima dari naskah drama. Bagian ini terjadi di Bangsal Witana. Dialog ini antara Damar Wulan dan Dewi Suhita. Dialog ini terjadi ketika Damar Wulan difitnah telah menyebarkan agama sesat dan menganggap bahwa sekarang agama hanya takhyul. Namun, kenyataannya adalah Damar Wulan menginginkan agar orang sadar bahwa Tuhan bukan berada dimana-mana tetapi diri sendiri.

\section{Kerinduan akan hadirnya suatu tatanan sosial yang hangat berdasarkan alur/plot}

Ciri romantisisme selanjutnya adalah kerinduan akan hadirnya suatu tatanan sosial yang hangat, seperti pada kutipan berikut:

Anjasmara: "Tuan berpangkat kesatria, bukan sudera dan pekerjaan ini tidak layak tuan kerjakan." (hlm 17)

Keterangan: Kesatria dan sudera adalah tingkatan kasta. Dalam tatanan sosial, hal tersebut seperti mengelompokkan manusia. Oleh karena itu, romantisisme rindu akan tatanan sosial yang hangat. Dialog ini terdapat pada bagian dua dari naskah drama. Dialog ini antara Damar Wulan dan Anjasmara (Kekasih Damar Wulan dan anak dari paman Damar Wulan.). Pada bagian ini menceritakan antara kasta, yaitu kesateria dan sudera. Selain itu, bagian ini menceritakan tentang keserakahan akan jabatan. Damar Wulan sebenarnya adalah seorang kesateria. Akan tetapi, Damar Wulan sesampainya berada di Majapahit dijadikan tukang kuda (kasta sudera). Dari ucapan Damar Wulan, terlihat jelas perbedaan antar kasta tersebut. Keserakahan pun tergambar pada bagian ini, seharusnya Damar Wulan kesateria. Namun, oleh pamannya (ayah Anjasmara), Damar Wulan justru dijadikan tukang kuda karena pamannya tidak ingin Damar Wulan menjadi pemimpin di Majapahit.

Damar Wulan: "Raden Ajeng Anjasmara, jikalau terjadi penghinaan kasta, negeri pun runtuh, tidak tertolong. Keadaan Majapahit jadi begini karena rakyat dihina-hinakan, diperas, dan dipijak. Sebulan baru saya di sini, tetapi sudah banyak kulihat. Kesatria menikam orang bawahan untuk mencoba tajam kerisnya. Sudera dpandang sebagai hewan, negeri buat kaum bangsawan. Kesateria sekalian kaya-kaya, rakyat meratap karena lapar. Dasar negeri sudah lapuk, sebentar lagi Majapahit hancur." (hlm. 17-18)

Keterangan: Penghinaan kasta, kesateria, dan sudera merupakan contoh yang terjadi dalam tubuh Majapahit. Hal tersebut sudah jelas digambarkan oleh dialog Damar Wulan. Dialog di atas mengungkapkan betapa angkuhnya kesateria kepada sudera dan hal tersebut menurut romantisisme merupakan garapannya yaitu rindu akan suatu tatanan sosial yang hangat. Dialog ini terdapat pada bagian dua dari naskah drama. Dialog ini antara Damar Wulan dan Anjasmara. Bagian ini menceritakan kesengsaraan rakyat jelata (kasta sudera). Rakyat jelata yang hanya dijadikan bahan percobaan atas keris sang kesateria. Kejadian yang kontras pun tergambar dalam dialog ini. Kesateria sekalian kaya raya, sedangkan rakyat meratap kelaparan. Suatu tatanan sosial yang hangat dan baik sangat diperlukan bagi kaum tertindas.

Anjasmara: "Yang kucintai Damar Wulan, bukan pekerjaannya sekarang ini. Aku tahu, bahwa tuan sudah jadi seperti ini, karena perintah yang tidak patut." (hlm. 18)

Keterangan: Perintah yang tidak patut adalah gambaran tentang buruknya tatanan sosial yang ada dalam Majapahit. Hal tersebut sesuai dengan romantisisme yaitu rindu akan suatu tatanan sosial yang hangat. Dialog ini terdapat pada bagian dua dari naskah drama. Dialog ini antara Damar Wulan dan Anjasmara. Bagian dua dari naskah ini memang menceritakan ketaatan Damar Wulan untuk Kerajaan Majapahit. Disaat dia dicundangi, justru dia menjaga apa yang diperintahkan.

Layang Setera: “... Ingat Anjasmara, engkau sudah dipinang oleh Adipati Singasari. Dan janganlah lupa akan pangkatmu..." (hlm. 20-21)

Keterangan: Pangkat dianggap yang penting dalam suatu sosial di Majapahit. Perbedaan tersebut membuat dampak sosial yang kurang baik. Oleh karena itu, ciri romantisisme yaitu rindu akan suatu tatanan sosial yang hangat cocok dalam permasalahan yang terjadi di Majapahit. Dialog ini 
terdapat pada bagian dua dari naskah drama. Dialog ini antara Layang Setera dan Anjasmara. Pangkat masih menjadi pembicaraan yang hangat dalam dialog ini. Pembedaan manusia masih sangat kental. Suatu tatanan akan hangat apabila kesenjangan ini bisa diatasi.

Dewi Suhita: "perkataan paman benar sekali, tetapi apakah patut diperbuat lagi? Cobalah sebut jalan yang baik. Waktu dulu kehormatan sungguh jadi kepala balatentara, sekarang sukar mencari orang yang suka jadi senapati." (hlm. 35)

Keterangan: Waktu dulu kehormatan sungguh jadi kepala balatentara, sekarang sukar mencari orang yang suka jadi senapati ialah bentuk romantisisme yang merindukan suatu tatanan sosial yang hangat. Dahulu kehormatan Majapahit sangat dijunjung, sekarang kepentingan pribadi jauh lebih penting. Dialog ini terdapat pada bagian tiga dari naskah drama. Dialog ini antara Dewi Suhita dan Utusan. Dialog ini menceritakan akan turunnya rasa kesateriaan dalam tubuh Majapahit. Apabila tentang kekuasaan dan jabatan, selalu memperlihatkan diri. Tetapi disaat perang, mereka menghilang. Pada bagian tiga, ciri romantisisme ini banyak ditemukan karena pada bagian ini berada di Bangsal Witana dimana berkumpulnya pengawa-pengawa.

Utusan: "Perabu, patik diutus tuan hamba Menak Koncar mempersembahkan kepada Perabu, bahwa Bupati Perabalingga telah menyerahkan ibu negeri kepada Adipati Menak Jingga."

Dewi Suhita: "Bertambahlah sudah orang durhaka. Di Jawadwipa tidak ada kesatria lagi. Pabila berangkat Menak Jingga untuk menyerang Majapahit?” (hlm 35)

Keterangan: Menak Koncar mempersembahkan kepada Perabu, bahwa Bupati Perabalingga telah menyerahkan ibu negeri kepada Adipati Menak Jingga dan bertambahlah sudah orang durhaka,di Jawadwipa tidak ada kesatria lagi menggambarkan bahwa terjadi pengkhianatan yang akan menyebabkan kemunduran dalam Majapahit. Bagian tersebut yang merupakan garapan romantisisme yakni rindu suatu tatanan sosial yang hangat. Dialog ini terdapat pada bagian tiga dari naskah drama. Dialog ini antara Dewi Suhita dan Utusan. Tergambar jelas bahwa terdapat pengkhianat di Kerajaan Majapahit. Utusan di utus oleh Raden Menak Koncar untuk memberitahukan bahwa Bupati Perabalingga telah menyerahkan ibu negerinya kepada Raden Menak Jingga. Menak Jingga adalah lawan yang akan dihadapi Majapahit saat berperang.

Damar Wulan : "memang rakyat mau berontak. Akan tetapi Perabu, adalah sebabnya. Rakyat sengsara bukan kepalang, karena kelakuan beberapa menteri karena yuran terlalu tinggi, karena harta tidak terlindung. Di kaki singgasana Seri Perabu orang banyak kelaparan dan meratap minta perlindungan. Perabu, patik enggan menumpahkan darah tidak bersalah.” (hlm 44)

Keterangan: Rakyat sengsara dan yuran terlalu tinggi, karena harta tidak terlindung melukiskan bahwa rakyat jelata sudah pasti sensara dan tertindas akibat ketidakberdayaanya. Oleh karena itu, Damar Wulan menginginkan rakyat jelata diperlakukan adil sehingga tatanan sosial yang hangat bisa terwujud. Dialog ini terdapat pada bagian tiga dari naskah drama. Dialog ini antara Damar Wulan dan Dewi Suhita. Dialog ini menceritakan saat-saat rakyat memberontak akan suatu tatanan yang kurang menguntungkan bagi rakyat. Rakyat selalu ditindas oleh hyb kesateria. Rakyat harus membayar yuran yang tinggi, harta yang tidak dilindungi, serta jiwa yang selalu terancam. Hal yang sudah menjadi rahasia umum pun ternyata tidak Dewi Suhita ketahui. Jelaslah bahwa pimpinan tidak pernah melihat kehidupan rakyatnya.

Patih : "Rakyat harus dikekang keras. Ia bukan dalam sengsara, hanya dibujuk orang khianat. Jikalau duli Seri Perabu memberi hati sekali saja, rakyat tentu bertambah berani dan meminta bertambah banyak.

Damar Wulan baru sebentar di Majapahit, tidak tahu keadaan negeri.

Beri perintah, Perabu, kepada senapati memaksa rakyat pulang ke rumah. 
Hanya tangan kuat dapat memerintah dengan selamat..." (hlm 44)

Keterangan: Rakyat harus dikekang keras dan Hanya tangan kuat dapat memerintah dengan selamat melukiskan bahwa rakyat adalah sesuatu yang rendah dan dapat ditaklukan serta dikuasai oleh yang kuat. Tangan kuat adalah sesuatu yang kuat, dimana bisa mengatur apa saja dengan kearoganannya. Dialog ini terdapat pada bagian tiga dari naskah drama. Dialog ini antara Patih dan Dewi Suhita. Patih menceritakan tentang yang kuat pasti akan menang dan yang lemah pasti akan kalah. Masih sama permasalahannya di bagian tiga yaitu adanya perbedaan antara yang lemah dan kuat serta rakyat jelata dengan kesateria.

\section{Simpulan}

Berdasarkan hasil peneleitian terhadap naskah drama Sandhyakala Ning Majapahit karya Sanoesi Pane diperoleh informasi tentang romantisisme. Kesimpulan yang didapat antara lain: (1) Naskah drama tersebut mengandung romantisisme; (2) Ciri romantisisme pertama, yakni kesadaran akan adanya alam liar. Ciri tersebut selalu berkaitan/bersamaan dengan tokoh Damar Wulan, Wisynu, dan Kamawijaya. Pada bagian 1 dan 2 terdapat banyak ciri romantisisme ini, (3) Ciri romantisisme kedua, yakni keunikan dan kekhasan individu seperti perasaan (passion) dan imajinasi hadir melalui tokoh-tokohnya. Perasaan yang dominan menguasai naskah drama ini muncul karena Damar Wulan difitnah akan keberaniannya, (4) Ciri romantisisme ketiga, yakni kerinduan akan hadirnya suatu tatanan sosial yang hangat seperti keberpihakan kaum tertindas (rakyat jelata). Pada bagian 3,4, dan 5 terdapat banyak ciri romantisisme ini, (5) Banyak ciri romantisisme yang terdapat dalam naskah drama ini. Hal tersebut menunjukkan bahwa disadari atau tidak oleh penulisnya, naskah drama Sandhyakala Ning Majapahit ini, memiliki perspektif tertentu. Jadi, naskah drama ini adalah naskah drama yang beraliran romantisisme.)

\section{Ucapan Terima Kasih}

Terima kasih kepada semua pihak yang membantu penulis dalam menyelesaikan artikel hasil riset ini sehingga bisa diterbitkan di Jurnal Hortatori.

\section{Daftar Rujukan}

Anirun, S. Menjadi aktor. Bandung: Studiklub Teater Bandung, 1998. Print.

Baumer, F. L. Modern european thouhgt. New York: Macmilan Publishing, 1977. Print.

Damono, S. D. dkk. Membaca Romantisisme Indonesia. Jakarta: Pusat Bahasa, 2005. Print.

Djojosuroto, K. Dasar-dasar teori apresiasi prosa. Jakarta: Universitas Negeri Jakarta, 2007. Print.

Endraswara, S. Metodologi penelitian sastra. Yogyakarta: MedPress, 2008. Print.

Esten, M. Kesusastraan pengantar teori dan sejarah. Bandung: Angkasa, 2013. Print.

Gani, R. Pengajaran sastra Indonesia respond dan analisis. Jakarta: Depdikbud Dirjen Pendidikan Tinggi Proyek Pengembangan Pendidikan Tenaga Kependidikan, 1998. Print.

Ghofur, A. Desain instruksional. Solo: Tiga Serangkai, 1998. Print.

Kratz, E. U. Sumber terpilih: sejarah sastra Indonesia abad XX. Jakarta: Kepustakaan Populer Gramedia, 2000. Print.

Ma'arif, E. S. Absurditas dalam naskah drama Arifin C. Noer. Yogyakarata: IAIN Sunan Kalijaga, 2001. Print.

Purwo, B. K. Bulir-bulir sastra dan bahasa pembaharu pengajaran. Yogyakarta: Kanisius, 1998. Print. Riantiarno, N. Menyentuh teater: tanya jawab seputar teater kita. Jakarta: MU:3 Books, 2003. Print.

Teeuw, A. Sastra dan ilmu sastra. Jakarta: PT Dunia Pustaka Jaya, 2013. Print. 